\title{
Pembuatan POC Limbah Sayur untuk Produksi Padi di Desa Lapang Kecamatan Johan Pahlawan Kabupaten Aceh Barat
}

\author{
Teuku Athaillah', Bagio $^{2}$, Yusrizal ${ }^{3}$, Sri Handayani $^{4}$ \\ Universitas Teuku Umar, \\ Jalan Kampus Alue Peunyareng Kecamatan Meureubo Kabupaten Aceh Barat ${ }^{1234}$ \\ Email: athaillah.teuku@utu.ac.id
}

\begin{abstract}
ABSTRAK
Pupuk Organik Cair (POC) adalah pupuk cair yang dibuat dari berbagai bahan alami. Bahan alami tersebut bisa berasal dari sampah dedaunan ataupun dari limbah dan sisa makanan. Sampah dan limbah makanan tersebut difermentasikan secara anaerob (tanpa oksigen) dan tanpa bantuan matahari. Tujuan Kegiatan ini untuk memperkenalkan pembuatan POC Limbah sayur terhadap masyarakat Desa Lapang. Adapun manfaat dari kegiatan ini adalah membantu masyarakat dalam pengelolaan sampah dan limbah rumah tangga dan mengajari masyarakat untuk membuat POC dari limbah sayur. Materi yang diberikan dalam kegiatan ini adalah bagaimana memanfaatan limbah sayuran menjadi produk yang bernilai ekonomis. Materinya antara lain tentang mengolah sampah menjadi pupuk organik cair. Materi diberikan dengan cara presentasi dengan menggunakan powerpoint. Masyarakat yang hadir pada saat berlangsungnya kegiatan pengabdian masyarakat berjumlah 20 orang. 70 persen yang hadir adalah wanita, sementara sisanya adalah pria. Pengabdian ini juga dihadiri oleh Penyuluh dari BPP Desa Johan Pahlawan. Cara pembuatan pupuk organik mampu disosialisasikan dengan baik kepada masyarakat Desa Lapang. Dampak dari pengabdian ini yaitu setelah mengetahui cara pembuatan POC, masyarakat Desa Lapang bisa merealisasikannya dengan cara membuat POC, menggunakannya dan bisa juga memasarkan POC tersebut.
\end{abstract}

Kata kunci: POC; Limbah sayur; Pengabdian

\begin{abstract}
Liquid Organic Fertilizer (POC) is a liquid fertilizer made from various natural ingredients. This natural material can come from leaves or from waste and food scraps. Waste and food scraps are fermented anaerobically (without oxygen) and without sunlight. The purpose of this service is to introduce the manufacture of vegetable waste POC to the people of Lapang Village. The benefits of this activity are to help the community in waste management and household waste and teach the community to make POC from vegetable waste. The material given in this activity is how to use vegetable waste into products of economic value. The materials include processing waste into liquid organic fertilizer. The material are given by means of presentation using a power point. There were 20 people who attended the community service activities. 70 percent attended were women, while the rest were men. This service was also attended by the Extension Officer from BPP Johan Pahlawan Village. How to make organic fertilizers can be well socialized to the people of Lapang Village. The impact of this service is that after knowing how to make POC, the people of Lapang Village can make it happen by making POC, use it and can also market the POC.
\end{abstract}

Keywords: POC; Vegetable waste; dedication 


\section{PENDAHULUAN}

Desa Lapang merupakan salah satu desa dalam Kecamatan Johan Pahlawan yang menjadi salah satu daerah penghasil padi terbesar diwilayah Kabupaten Aceh Barat. Masyarakat Desa Lapang pada umumnya memiliki lahan yang luas untuk budidaya padi. Masyarakat Desa Lapang di dominasi oleh para wanita yang mempunyai pekerjaan tetap sebagai petani padi.

Meningkatnya kebutuhan akan beras sebagai makanan pokok tidak selalu diberangi dengan meningkatnya jumlah produksi padi. Banyak petani yang tidak bisa mencapai jumlah produksi optimum yang disebabkan oleh berbagai kendala. Kendala tersebut diantaranya faktor cuaca, kondisi lahan dan faktor sumberdaya manusia pada masyarakat tani.

Rendahnya produksi padi salah satunya disebabkan oleh kurangnya pengetahuan petani terhadap proses pemupukan. Petani hanya mengetahui pupuk yang digunakan pada tanaman padi adalah pupuk berbahan kimia. Sedikit sekali petani yang menggunakan pupuk organik pada tanaman padi. Padahal pupuk organik adalah pupuk alami yang paling aman digunakan baik untuk padi, tanah, maupun untuk konsumen yang mengkonsumsi hasil padi tersebut nantinya.

Pembuatan pupuk organik dari sampah dan limbah juga bisa mengurangi jumlah sampah dimasyarakat. Pengelolaan sampah membutuhkan sejumlah tenaga, tergantung dari besar kecilnya permasalahan sampah yang dikelola (Sumantri, 2013). Perilaku membuang sampah sembarangan sangat sulit dihilangkan karena sudah menjadi kebiasaan. Perilaku buruk ini semakin sulit dihilangkan karena minimnya sarana kebersihan seperti tong sampah yang mudah dijangkau oleh masyarakat pada tempat umum.

Salah satu bentuk pengelolaan sampah adalah dengan membuat pupuk kompos. Kompos adalah bahan organik yang dibusukkan pada suatu tempat yang tertutup dari cahaya matahari, pupuk kompos juga diatur kelembabannya dengan cara menyiram air agar tidak kering. Pupuk organik berperan dalam memperbaiki sifat fisik, kimia, dan biologi tanah (Hapsari \& Welasi, 2013). Penggunaan pupuk organik bermanfaat untuk memperbaiki kesuburan tanah dan menambah unsur hara yang diperlukan oleh tanaman (Hamzah., 2014). Untuk mempercepat perombakan dapat ditambah kapur, sehingga terbentuk kompos dengan $\mathrm{C} / \mathrm{N}$ rasio rendah yang siap untuk digunakan. Bahan untuk kompos dapat berupa sampah atau sisa makanan. Pupuk kompos bisa bentuk padat 
ataupun cair (Roidah, 2013).

Pupuk Organik Cair (POC) adalah pupuk cair yang dibuat dari berbagai bahan alami. Bahan alami tersebut bisa berasal dari sampah dedaunan ataupun dari limbah dan sisa makanan. Sampah dan limbah makanan tersebut difermentasikan secara anaerob (tanpa oksigen) dan tanpa bantuan matahari (Prihandarini, 2014). pada saat proses pembuatan bisa ditambahkan larutan mikroorganisme untuk mempercepat proses pendegradasian.

Tujuan Kegiatan ini untuk memperkenalkan pembuatan POC Limbah sayur terhadap masyarakat Desa Lapang. Adapun manfaat dari kegiatan ini adalah membantu masyarakat dalam pengelolaan sampah dan limbah rumah tangga dan mengajari masyarakat untuk membuat POC dari limbah sayur.

\section{METODE}

\subsection{Materi yang diberikan}

Materi yang diberikan dalam kegiatan ini adalah bagaimana memanfaatan limbah sayuran menjadi produk yang bernilai ekonomis. Materinya antara lain tentang mengolah sampah menjadi pupuk organik padat dan cair. Meteri diberikan dengan cara presentasi dengan menggunakan powerpoint.

Materi yang diberikan diantaranya adalah bagaimana membuat pupuk organik cair maupun padat dari sampah dan sisa limbah rumah tangga. Pupuk organik padat bisa digunakan oleh masyarakat untuk menyuburkan tanaman. Pupuk organik cair bisa digunakan oleh masyarakat untuk tanaman serta bisa dijual dipasaran.

\subsection{Metode Kegiatan}

Kegiatan ini dilakukan dengan metode pelatihan berupa pemaparan materi mengenai pemenfaatan limbah dan sisa makanan dan limbah sayur untuk membuat pupuk organik cair. Setelah dilakukan pemaparan materi oleh dosen kemudian dilakukan sesi tanya jawab dengan petani.

\subsection{Waktu dan Jadwal Kegiatan}

Kegiatan pengabdian masyarakat ini dilakukan di Desa Lapang pada tanggal 17 Oktober 2019. Adapun waktu pelaksanaan kegiatan nya dapat dilihat pada tabel 1. 
Tabel 1. Jadwal Kegiatan Pengabdian Kepada Masyarakat

\begin{tabular}{|c|c|c|c|c|c|}
\hline \multirow{2}{*}{ No } & \multirow{2}{*}{ Kegiatan } & \multicolumn{4}{|c|}{ Jam } \\
\hline & & $\begin{array}{ll}09.00 & 12.00\end{array}$ & 14.00 & 15.00 & 17.00 \\
\hline 1 & Pembukaan Acara & & & & \\
\hline 2 & Presentasi & & & & \\
\hline 3 & Diskusi & & & & \\
\hline
\end{tabular}

\section{HASIL, PEMBAHASAN, DAN DAMPAK}

Masyarakat yang hadir pada saat berlangsungnya kegiatan pengabdian masyarakat berjumlah 20 orang. Hampir $70 \%$ yang hadir adalah wanita, sementara sisanya adalah lakilaki. Pengabdian ini juga dihadiri oleh Penyuluh dari BPP Desa Johan Pahlawan.

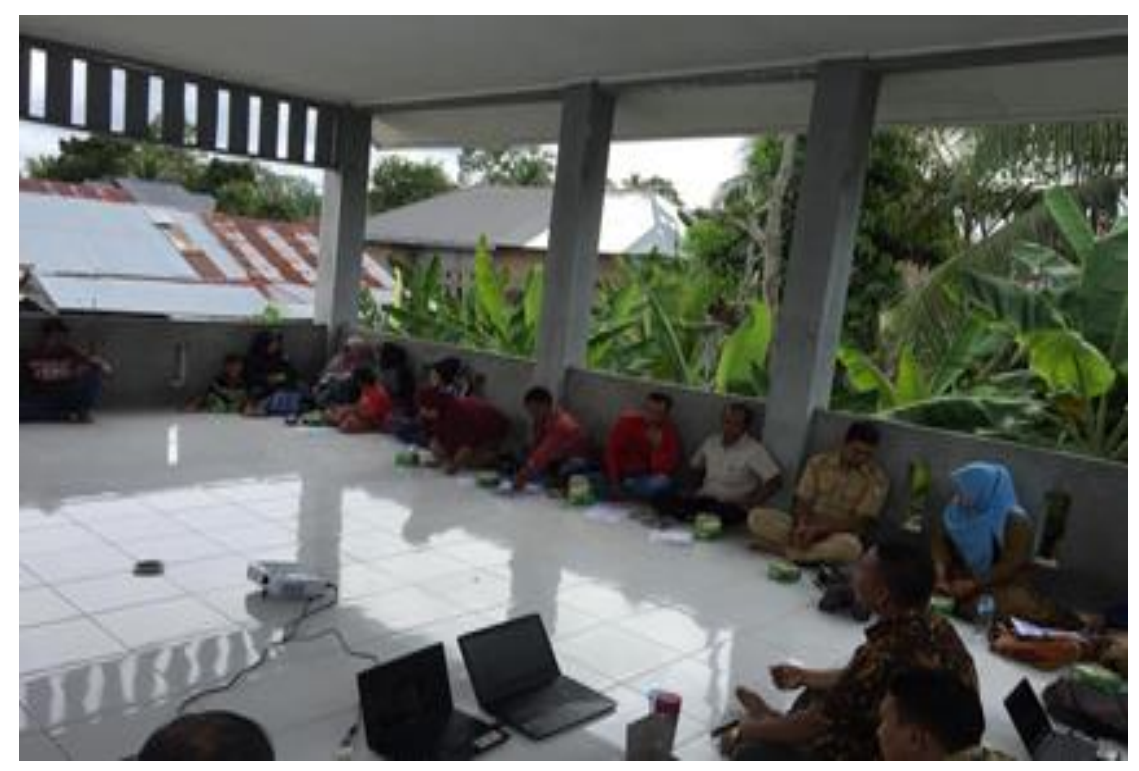

Gambar 1. Masyarakat yang hadir

Kegiatan dilaksanakan selama satu hari yaitu dengan pemberian materi tentang mengolah limbah sayur menjadi pupuk organik. Materi dibagikan kepada petani dalam bentuk hardcopy dan juga disajikan dalam bentuk power point dengan cara di presentasikan. Setelah dilakukan presentasi dilanjutkan dengan sesi tanya jawab. Masyarakat menyambut semua materi yang diberikan dengan sangat antusias, hal ini dapat dilihat dari jumlah masyarakat yang hadir sebanyak 20 orang. Kemampuan peserta dalam memahami materi cukup baik. 


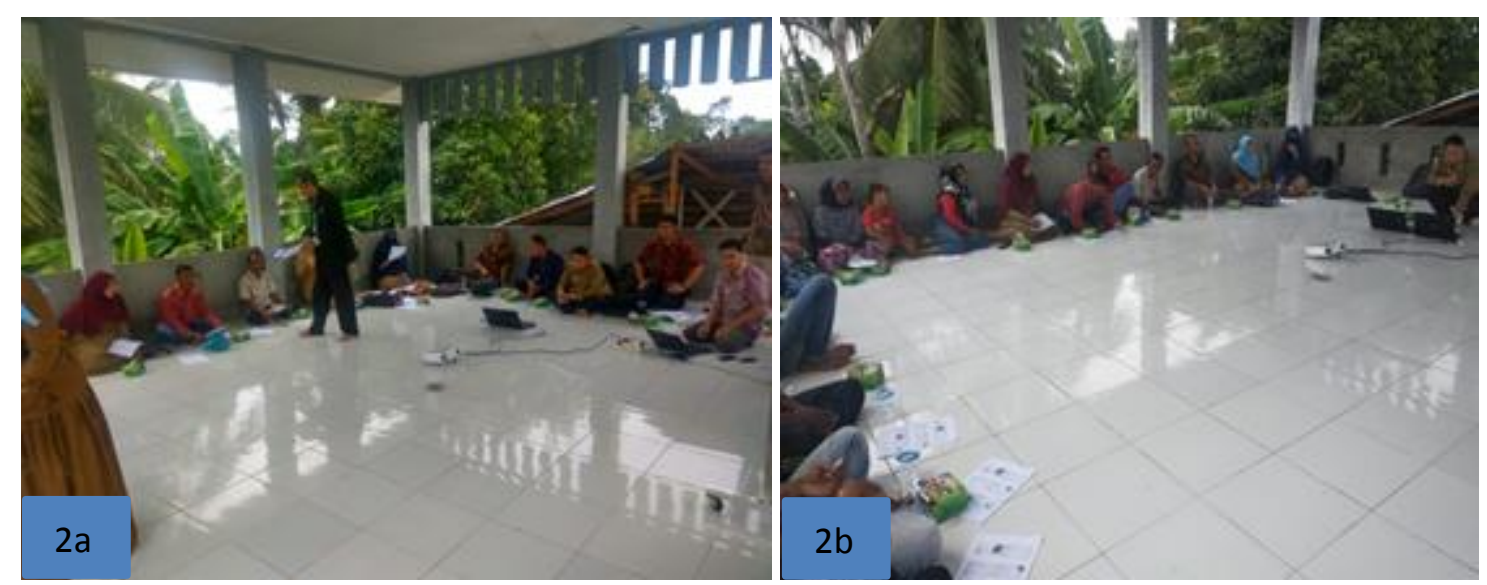

Gambar 2a. dan 2b. Kegiatan Pembagian materi kepada petani

Evaluasi dilakukan dengan melihat pemahaman masyarakat terhadap pembuatan pupuk organik cair dari bahan limbah sayur. Adapun proses evaluasi yang dilakukan adalah dengan menanyakan kepada petani tentang materi yang telah diberikan. Pertanyaanpertanyaan tersebut mampu dijawab oleh petani dengan sangat tepat dan akurat.
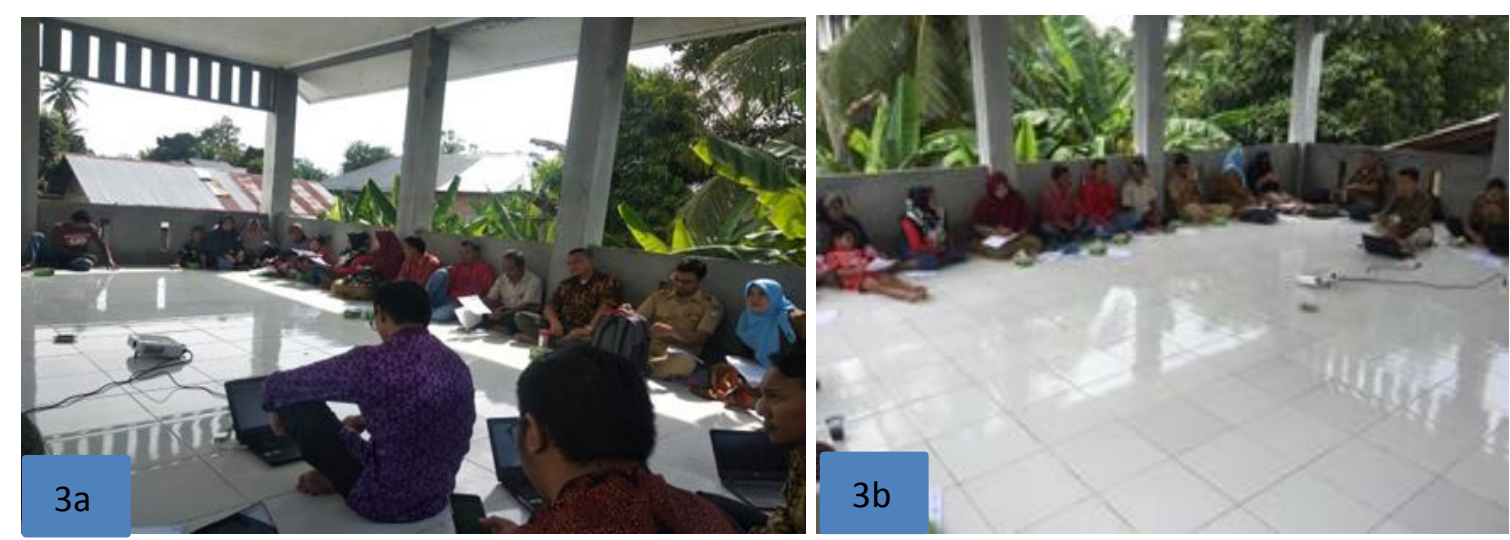

Gambar 3a. dan 3b. Kegiatan Dilakukan Evaluasi terkait Materi yang diberikan

Dampak dari dilakukan pengabdian ini adalah petani Desa Lapang mengetahui cara pembuatan POC. Petani bisa mengurangi pemakaian pupuk kimia dengan cara membuat sendiri POC dan menggunakannya di lahan pertanian padi. Selain untuk digunakan sendiri, petani juga bisa memasarkan POC tersebut kepada petani yang berada didaerah lainnya.

\section{SIMPULAN}

Cara pembuatan pupuk organik mampu disosialisasikan dengan baik kepada masyarakat Desa Lapang. Dengan mengetahui cara pembuatan pupuk organik masyarakat Desa Lapang mampu untuk merealisasikannya dengan cara membuat pupuk organik tersebut dan bisa di pasarkan. 


\section{DAFTAR PUSTAKA}

Hardiatmi, S. 2011. Pendukung Keberhasilan Pengelolaan Sampah Kota. INNOFARM. Jurnal Inovasi Pertanian, 10(1): 50-66.

Nadiasa, M., Sudarsana, D.K., Yasmara, I.N. 2009. Manajemen Pengangkutan Sampah Di Kota Amlapura. Jurnal Ilmiah Teknik Sipil, 13 (2) : 120-135.

Roidah, I. S. 2013. Manfaat Penggunaan Pupuk Organik Untuk Kesuburan Tanah. Jurnal Universitas Tulungagung BONOROWO 1(1).

Suyono \& Budiman. 2010. Ilmu Kesehatan Masyarakat Dalam Kontek Kesehatan Lingkungan. Jakarta: EGC

Sumantri A. 2013. Kesehatan Lingkungan. Jakarta:Kencana Prenada Media Grup.

Hamzah, S 2014, 'Pupuk organik cair dan pupuk kandang ayam berpengaruh kepada pertumbuhan dan produksi kedelai (Glycine max L.)', Agrium: Jurnal Ilmu Pertanian, vol. 18, no. 3, pp. 228-234. 